Meta

Journal des traducteurs

Translators' Journal

\title{
The Role of the Translator of African Written Literature in Inter-Cultural Consciousness and Relationships
}

\section{S. Ade Ojo}

Volume 31, numéro 3, septembre 1986

Prismes de traductions littéraires

Facets of Literary Translation

URI : https://id.erudit.org/iderudit/003759ar

DOI : https://doi.org/10.7202/003759ar

Aller au sommaire du numéro

Éditeur(s)

Les Presses de l'Université de Montréal

ISSN

0026-0452 (imprimé)

1492-1421 (numérique)

Découvrir la revue

Citer cet article

Ojo, S. A. (1986). The Role of the Translator of African Written Literature in Inter-Cultural Consciousness and Relationships. Meta, 31(3), 291-299.

https://doi.org/10.7202/003759ar d'utilisation que vous pouvez consulter en ligne. 


\section{THE ROLE OF THE TRANSLATOR OF AFRICAN WRITTEN LITERATURE IN INTER-CULTURAL CONSCIOUSNESS AND RELATIONSHIPS*}

S. ADE OJO

UNIVERSITY OF LAGOS, LAGOS, NIGERIA

It has been estimated that the world has about 4200 autonomous languages through which its almost 6 billion inhabitants ${ }^{1}$ communicate with one another. It has also been established that at least three quarters of these languages have not yet been worked upon by trained linguists to allow them to be represented by linguistic signs which would have made them useful for communicating written information. Even then, out of those languages that are written, not more than one hundred and forty are used for publication. Less than ten percent of the publications made in these languages manage to cross their geo-political, cultural and linguistic frontiers. Those which have succeeded in going beyond their original sources fall into two broad categories.

The first category consists of texts written in languages belonging to the same language family with branches spreading out from the radiating nucleus, as a result of migration or expansionism (through conquest, colonization, political domination, assimilation or self-styled civilizing mission). In this category are publications written in such languages (of colonization) as English, French, Spanish, Portuguese, German and Dutch, with their roots in Europe and their off-shoots in Africa, Asia, Australia and the Americas. Russian, because of its cataclytic political force, has succeeded in implanting its super-imposing influence on many East Europe countries as well as other countries outside Europe which share the political ideology of the USSR. Russian is, therefore, a language of political or ideological conquest, and publications made in it have not had much problem in "invading" countries where the political hegemony of the USSR is paramount. Publications made in such languages of domination identified above therefore travel beyond their countries of origin to other countries where such languages are used for intranational communication, with ease and without the intermediary of "secondary" writers.

With the second category of texts, however, there have to be "secondary" writers. Each of these intermediary writers is the one who, having read and thoroughly assmilated the original text, helps to transfer the message(s) expressed in the source or original language into another language by (ideally) ensuring that the totality of the meanings : the conceptual meaning and the communicative value, of the text is preserved and conveyed in the target language as accurately as possible and in a manner that will show responsiveness to the text's linguistic and extra-linguistic reality. The technical term used for this intermediary writer is the translator. Through him, the text which would have been unable to cross its native linguistic habitat is accorded a right of place in another linguistic community. The text is therefore made accessible to a reader who speaks a different language, who lives in a different time and place and who belongs to a different cultural tradition from those of the original writer of the text. 
The identity of this "intermediary" writer has been misunderstood by many scholars. He is given such negative terms as "traitor", "murderer", "le bel infidèle". These titles are given to him because of language and other academic crimes resulting from the translator's intellectual ineptitude or lack of professional training. These deficiences invariably lead to the message(s) in the source text being destroyed with over-translation (excessive commentary, explanation, interpretation and padding), with undertranslation (paraphrase, adaptation) and with mistranslation (howlers, errors, slips, wilful reshaping). As an African adage says, "a bad character can bring dishonour to a multitude of others". A bad translator, who succeeds in producing a target text that is inadequate to its source text, is capable of spoiling the honour of the good translators who abound in thousands all over the world. A few howlers, slips and other translation faults in a target text can also negate the overall positive effects that the text would have had on its new audience.

However, a bad translation of a text is still better than the absence of translation of the text since the unilingual reader or the reader ignorant in the language of the ST (source text) would have been deprived access to the text. Though such a bad translation is capable of having an immediate negative effect on the reader, he may be able, through supplementary readings and additional enquiry, to correct the original faulty impression created in him by his first contact with the text. This does not, however, imply that we want to praise incompetent translators or shower accolades on defective, that is misconstrued, inadequate and superficial, translations.

We are in this article concerned with the positive effects of translation on the cross-pollination of ideas, on inter-cultural consciousness and relationships, as this can be seen in African literary texts translated from their source languages. We are here concerned with translation as a pluri-disciplinary field of interest ; one which is not only an art of linguistic mastery but a philological art and an art of cultural contact. We want to show the translator as a committed genius who combines the personalities of the linguist, the thoroughly cultivated scholar, the critic and the creative writer and who, because of the enormous work of analysis, exegesis, elaboration and reformation involved in the translation process, has to recreate the source text.

In order to be able to effect his mission as an agent of inter-cultural exchange and understanding, the translator has to show evidence of some natural and acquired skills. This means that, in addition to his intuitive intellectual ability, he must be knowledgeable in the art of translation. He must also be armed with a sound scholarship of the ST's social, cultural and literary backgrounds and must have mastered the technolect relevant to the literary genre (to which belongs the ST) as well as to the subject matter in order to arrive at what Steiner called "the dynamic counterpart" of the opposing ST. He must above all have a deep understanding of the mind of the writer whose work is being translated. Because of the linguistic and extra-linguistic demands of translation, the translator must not only be a master of the language from which he is translating, but he must also have a thorough love for the language ${ }^{2}$ into which he is translating, so that his ability to employ a level of the target language that is understood by the reader and acceptable to the subject-matter and style of the source language is guaranteed. He must therefore be a proficient bilingual, a brilliant intellect and an artist with words. These are qualities that will enable him to measure the communicative value as well as the deep sense of the ST and replace it by a TT (target text) in a receptor language which approximates as closely as possible the same communicative value. To do this successfully, he must be able to identify and distinguish culture-bound, structure-bound and time-place - tradition bound elements in the ST and express them adequately in the 
target language. It is through this ability that the translator will produce a rendering of the ST which will fit, according to Nida,

the receptor language and culture as a whole, the context of the particular message, the receptor language audience ${ }^{3}$.

As for African written literature, the receptor languages involved in translation are African languages, Arabic and such international contact languages of colonization as English, French, Spanish and Portuguese. The latter which are languages of intranational, inter-regional and international communication in Africa have each become the lingua franca or the official language in the country into which it was introduced by the colonizing country. They are the languages used mostly in writing creative works and in translating such works. The reasons for this privileged position are legion. They range from the preference of the creative writers (who express themselves best in European languages which are also the languages of instruction in their respective countries) to the commercial and ethnic interests of Europe-based publishers (who would publish books whose market-values would be enhanced by the satisfaction the books give to European readers, who constituted, before independence, the bulk of the reading public). These reasons not only determine the choice of language of the creative writer but also the choice of the receptor language of the translator and of the book to be translated.

Apart from such religious texts as the Holy Bible, the Koran, the catechism, hymn books and such high-pitched religious propaganda writings as John Bunyan's The Pilgrim's Progress translated into some indigenous African languages, the publishers who were initially European (therefore serving European cultural, economic and political interests) showed little interest until early in the 60s, in encouraging, initiating and sponsoring the translation of African literary texts into other European or even indigenous African languages. This attitude was to be expected because the messages of African creative writers, mostly vitriolic and caustic, were directed primarily at the colonial masters. The natives, most of whom were illiterate, were the secondary audience. Encouraging literary works to move beyond their original geo-political and linguistic sources, through translation, would have meant helping to internationalize or globalize the African cause. It would also have sensitized educated and articulate Africans from the other linguistic groups and make them become fully aware of the predicament of the African. This pervasive political constraint definitely had a very negative effect on the translation of literary texts. Just as the publishers were little disposed to the encouragement of translating texts, so too are European scholars or professional translators impeded by the same ethnocentric political and economic considerations. But, more than anything else, the would-be European translators were confronted with another serious problem which derived from their intellectual responses to the specificity of African literary works.

It must be admitted that every work of art is moulded into an artistic object from varied levels of human experiences : pan-human or universal level, racial level, national level, ethnic level and the private experience of the creative artist. These can be broadly categorized into the two areas of collective and private experiences. However, literature, when compared with such non-verbal arts as music, dancing, painting, sculpture and opera among others, is the most expressedly affected, of all the artistic manifestations, by the last four of the levels of experiences outlined above. This is because of the language specificity, the ethnocentric concern and the distinct personal, creative and affective activity that go into the composition of the literary work. This is to say therefore that every literary object, definitely bound by a distinct geo-political specificity and con- 
ditioned by a particular creative ingenuity and affectivity, reflects a peculiar national temperament, a specific cultural tradition, a particular artistic convention and definite historical and economic determinants. It is a product of a culture and therefore of a people's way of life and of the values or norms inherent in the society in which it is rooted. Therefore, on the collective level, every African literary text reveals the spiritual, emotional and ethnic particularity of the African society from which the work has taken its root. It reflects the thinking pattern, the psyche and the mind of the African people and their responses to the realities of life. It therefore becomes the expression of the people's thoughts and language as well as their extra-linguistic reality.

A non-African, unfamiliar with these historical and experiential realities of the African, will find it impossible to understand and appreciate them in the literary work in which they are reflected and express them adequately in a language that is different from that of the source text. Familiarity can be achieved either by physical contact with the geo-political and cultural reality in which the work is rooted or by psychological and intellectual commitment to and understanding of the experience presented in the work. This special quality was lacking in most of the pre-independent non-African scholars. The deficiency contributed in no small measure to the dearth of translated African texts.

Apart from the extra-linguistic factors indicated above, the other most important literary phenomenon is the personal style of the artist : his choice of words and expressions, his arrangement of these language components. These have to be thoroughly grasped before any successful translation of his text can be done. To do a correct translation of each word or expression in the text, its conceptual context and emotional thrust must be understood. This is particularly indispensable because every work is chosen by the (original) creative artist for reasons varying from the emotional to the intellectual and the ideological. Moreover, the artist is never oblivious of the fact that the language he is using is linked to a community which has a distinct world-view and a peculiar language identity. Apart from this, he also knows that every word is polysemous in nature : it has a first meaning, a synchronic pertinence and a value depending on the conceptual context or plane in which it is placed. All these are to show that despite the fact that a word or expression is arbitrarily conditioned by the writer's society or his language community to designate something, its use is determined by the writer's private code or idiolect dictated by the peculiar circumstance or context in which the creative process is taking place, and also by the writer's personal intellectual and experiential background and finally by his ideology or conception.

In creating his work, the literary artist exploits, as he fancies, the open-ended process in communication. He uses words as he can and likes but also from the perspective of his own cultural and intellectual background. This is particularly so for the African writer who is basically bilingual - in his mother tongue and a language of colonization. Because of this dual linguistic 'mandate', he uses the European language differently from his metropolitan counterpart, by altering it, "to suit its new African sorrounding", to use Achebe's phraseology4.

The result of this is that most African writers have so localized the use of their acquired European languages by passing them through the matrix of their own cultural background that much of their work may be lost to the uninitiated non-African translator whose only recommendation for competence and suitability is that he is working into his own mother-tongue. This is why Gabriel Okara's experiment in The Voice may be difficult to transfer into a different European language, except by an Ijaw translator. So, too, will Ahmadou Kourouma's les Soleils des indépendances prove knotty to the non-Ivoirian translator. Soyinka's interlarding of most of his works with Yoruba words 
and expressions will create enormous headaches for the non-Yoruba speaking translator.

The fact of the case is that, though by his educational exposure and intellectual experience, the African writer has acquired a metropolitan literary inheritance and has mastered the rudiments of a European language, his head and ears have been tuned to the rhythm and expressions of his indigenous language which he (like Okara, Tutuo.la, Ousmane, Kourouma and even Soyinka) transliterates. This is why his style cannot but be different from that of his metropolitan counterpart. The Africanness of his work is, apart from the themes and characters in the work, created by the images, figures of speech and other rhetorical devices drawn from the African orature and environment. He also enriches his work with proverbs defined by Achebe as "the palm oil with which words are eaten" and by the Yorubas as "the horse of discourse, used for retrieving communication when it is lost". Besides, he colours his works at times with pidgin to make the language respond more realistically to the prevailing mentality. On the whole, one may safely say that the dual culture of the African writer makes him first and foremost a translator before being a creative artist.

Of a fact, some of them very consciously want the reader to know that they are first and foremost translators. Among these are the folktale writers. A few novelists also adopt a technique that reveals their original identity as translators. In Ferdinand Oyono's Une Vie de Boy, one reads at the beginning of the novel :

Il (le journal de Toundi) était écrit en ewondo. l'une des langues les plus parlées au Cameroun. Je me suis efforcé d'en rendre la richesse sans trahir le récit dans la traduction que j'en fis et qu'on va lires.

This means therefore that the literary object, released to the public by the publisher on behalf of the writer, is a combined version of other literary byproducts resulting from an indigenous speech pattern, thinking pattern and world view. All these are transliterated into the European language. But, as pointed out earlier, this translated version still retains vernacular expressions, local names of objects, places and human beings which are untranslatable but which succeeded in informing every reader of the text of the peculiarity of the society which has given birth to the literary object. Moreover, the contextual (i.e. intralingual) translation or explanation of local terms, customs and concepts is also done, as can be seen in the works of such writers as Achebe, Nzekwu, Soyinka and Senghor. It is also seen that while almost every one of the writers uses footnotes, some others incorporate glossaries and appendixes into their works by way of explaining culture-bound elements. Again, the use of illiterate characters in most of the works shows that what is being read is in fact what was in reality. One may also want to say that the merging of different characters from different distinct social classes and intellectual backgrounds into a body of fictional characters speaking the same polished language shows that the writer has translated their speeches into his own private codes!

While the translator of a literary product (born and nurtured in a European country) has to take into consideration just two cultures coming into contact, the translator of an African text finds himself battling with at least FOUR cultures. The source text (ST) represents two cultures : a European linguistic and literary culture and an indigenous linguistic and extra-linguistic experience. The target text (TT), on the other hand, embodies four cultures : the two that are conveyed by the European language as well as the underlying vernacular language of the ST and the two that the TT is trying to communicate. The translating process cannot but go therefore through a "re-structuring of the cultural system of signs ${ }^{6 "}$. To be effectively achieved, this re-structuring of the signifié has to be accompanied by a thorough understanding of the thinking patterns and the 
structural and grammatical systems of the confronted languages. The re-structuring is also accompanied by a careful appraisal and a reasoned perception of the linguistic and metalinguistic levels of representation of each of the confronted languages. The restructuring has to be done with the awareness that the translator is dealing with a work of imagination with its specific factual and affective realities.

We have gone to this extent, because we want to show that the non-African translator is faced with very stiff intellectual problems. Not only is he to be faced with the African version of the European language that he is to translate from but he has to do a very thorough study of the socio-cultural backgrounds against which the ST is written and where the TT will be read. The translated version of the ST must therefore have a tinge of Africanness ; it must also possess the style of the original text and express very appropriately the mind of the writer. The translator can therefore not fail to possess a literary sense that is sharpened by a creative resourcefulness. For these reasons, the state of the translation of African literary texts into European languages (and also into indigenous ones) could not but be gloomy before the $60 \mathrm{~s}$.

This gloomy state was again helped by the educational policy of the colonizing country. Under the colonial educational system, every educated indigene was restricted to the learning of the language of the colonizing master and the classics : Latin or Greek. This meant that no educated African, trained especially in his native country, could be proficient in two languages of colonization. The effect of this on the African literary scene was that African translators were virtually non-existent before the advent of independence (when the educational policy underwent a change for the better and accommodated the learning of other European languages). The inescapable consequence of this was that African works could not be translated by Africans themselves.

The overall result of these factors is that very little translation of African works was done into the other European languages, before independence. The choice of the few texts translated was representative of the mentality of the European translators. The first adapted African literary text from English into French was Tutuola's quaint story, The Palm-Wine Drunkard (published in 1952) which won European admiration because of its negative qualities - its amorphous generic identity (which makes the work defy categorization), its ungrammatical and unconventional English and its macabre pervading fantasy. The adaptation (and not the translation) in French of the text by Raymond Quéneau (in 1953) was to show the francophone world an example of what the blacks were capable of doing or rather not doing well. Otherwise, there would have been no reason to justify why better works written in English by such writers as Ekwensi, Achebe, Aluko, Dazi, Ako, Joseph Casely Hayford did not enjoy the same privilege of being translated or even adapted as fast as Tutuola's was done. The first work translated from French into English was Camara Laye's l'Enfant noir (1953) whose choice by James Kirkup (1955) must have been based on its award-winning quality (of the Swiss Prix Charles Veillon in 1954) and on its thematic perspective which among others shows the European self-arrogated civilizing mission as having an enduring and seductive impact on the impressionistic mind of a young African. Other works published before and immediately after l'Enfant noir by such writers as Birago Diop, Bernard Dadié, Beti, Ferdinand Oyono, Paul Hazoumé, Sembène Ousmane, Seydou Badian etc. did not succeed in winning the hearts of ready European translators. Even the Collection Unesco d'œeuvres représentatives created in 1948 through Roger Caillois with "the objective of contributing to the mutual appreciation of the diverse cultures by the translation of literary works by member states of the UNESCO" could not recommend them for the rights to enjoy the privileges reserved for the (full) member states of UNESCO. One can say therefore that before independence, the few works which en- 
joyed the special privilege of being translated were so translated by Europeans mainly for Europeans. The inter-cultural consciousness which ought to be basic to translation is rather one directional.

But with independence and the attendant growing interest in intra-continental, inter-regional and inter-linguistic co-operation in Africa, the translation of African literary works has attained a very impressive scale. Not only are more European translators and publishing houses showing growing interests in the translation of African literary texts but Negro African - sponsored or Africa - based publishing houses (like Clé, Heinemann and Présence africaine) seem fully committed to the translation of African literary texts. Indigenous translators who are professionally trained (like Olga Simpson), who are University critics, teachers and researchers (like Simon Mpondo, John Abioye, Timothy Asobele, D'Alméida, Bode-Thomas, Wole Soyinka) and who are self-translating creative writers (like Guillaume Oyônô-Mbia) have become part of the team of translators described by Nicholay Chukovsky as "the muse of friendship and fraternity". Unlike what it obtains in other literatures, the translation "business" (as it obtains in the economic or industrial sectors in Africa) is managed by both nonAfricans belonging to the TT linguistic source and Africans whose acquired second language is that of the TT. However, there are many more non-Africans in the "business".

That this upsurge of interest has greatly contributed to the inter-cultural awareness of Africans is not in doubt. As a Yoruba adage says, "the child who has not been privileged to visit another man's farm, will always think that his father's farm is the biggest and the best". The opportunity offered by the translator to Africans to read works written originally in languages other than their own does not only open to them a larger perspective through which are gleaned the cultural values of the particular societies in which the works are rooted, but it also allows them to identify the various attitudes of members of these societies to their existential situations, conditioned by varying factors. Among these factors are the divergent versions of colonial systems and the accompanying imposition of a foreign culture, alienation, acculturation, debasement, oppression, psychological emasculation and systematic mystification. The other conditioning features are independence (and the various responses of the society to the exigences of selfrule or self-determination) and traditional cultures (which vary from one society to the other). The translation of texts allow Africans to know that almost all creative works written before independence by Africans are basically de-colonizing in tone and perspective. This makes each of such works a form of counter-assertion by assertion, of systematic demystification by a form of mystification, and of revolt by disclosure and protest.

There is no doubt about the fact that Africans have been having, even from the pre-independence period, many opportunities to meet, exchange ideas and understand each other. These opportunities include Pan-African Congresses (from 1919) and meetings of scholars, critics and creative writers (from 1956). But these privileges were restricted to a very negligible and select few : internationally recognized scholars and political activists. And so, the majority of educated Africans were restricted to their cultural shells, conditioned by the codes of their respective linguistic and colonial groups.

Little or nothing was known by the majority of English speaking Africans of such writers of French expression as Beti, Oyono, Matip, Senghor, Diop, Ousmane and Dadié, until after independence when some of their works were translated into English. The whole hue and cry about negritude and tigritude did not gain ground until after independence. Such writers as Chinua Achebe, Soyinka and Ekwensi were hardly known beyond their names by educated francophone Africans. The psychological responses of Africans to colonialism and the various aspects of the colonial system as practised by 
every colonizing country treated by creative writers were known only by those who belonged to the same colonial and linguistic group. The various cultural values and manifestations which have indigenous variations from country to country and even from one ethnic group to another and which are generally best revealed in creative works did not gain currency beyond their restricted linguistic habitat. Francophone Africans did not really understand their anglophone counterparts, neither did the anglophone ones fare any better. Because of lack of understanding, little co-operation was facilitated between Africans who were more or less restricted to their linguistic cocoons.

These are the problems which translation, in spite of the fact that it has not succeeded in affecting up to five percent of African works, has tried to tackle. It must be mentioned, however, that those works that have been translated belong to the best and the most representative in each linguistic group, except that little or nothing is as yet known about the new generation of young writers beyond their linguistic communities.

The effect which the translation of works can have on the reading public has been aptly described by Paul Valéry when he said :

Réunissons les meilleurs de nous-mêmes et enrichissons-nous de nos divergences même.

This is very close to what Amadou-Mahtar M'Bow said in 1979 in Sofia :

Percer les secrets d'une langue, accéder aux grandes œuvres qu'elle a suscitées, c'est déjà commencer à saisir l'identité d'un peuple. [...] Lire un poète, un romancier, ou saisir un philosophe, ce n'est pas seulement converser avec lui, mais par son intermédiaire, saisir l'âme de la communauté culturelle à laquelle il s'identifie ${ }^{8}$.

The idea expressed here by M'Bow is not far from what the 19th General Conference of the UNESCO, the organisation of which he is the Director, approved in 1976 in Nairobi :

La traduction favorise la compréhension entre les peuples et la coopération entre les nations en facilitant la diffusion des oeuvres littéraires, scientifiques et artistiques au-delà des barrières linguistiques, ainsi que les échanges des idées.

All these statements underscore the truth that translation plays an indispensable role in the cross-pollination of cultures as well as in putting at the disposal of each language used in translation, the wide communication functionality of language.

The target language as well as the literature written in it benefits a lot from translation. The language benefits through the adaptation and the absorption of loan words, neologisms modelled after words in the source language, new culture-linked metaphors, the resources of other prosodic features, new symbols, new local lexical items and new syntactic patterns. The literature written in the target language benefits through the absorption of new stylistic devices and new interpretations of themes. The literature is also provided with examples of other possibilities or limitations of literature. These are some of the reasons which made Lefevère consider the translator as

his national literature's "antenna", picking up new and unfamiliar sounds. He is a literature's safeguard against parochialism and in-breeding. [...] Translation is, therefore, not only any literature's link with the tradition it is a product of, but also any literature's potentiality for change and rejuvenation ${ }^{9}$.

Apart from the gains for the target language and the literature written in it, members of the audience of the newly introduced (foreign) text benefit a lot from their reading of the text. By being helped to broaden their intellectual and socio-political horizons, they are given the awareness of being part of the African continental community 
as well as the global spiritual community. They are also afforded the opportunity to appreciate the relativity of cultures. Moreover, they are enabled to enlarge their sense of humanity and to appreciate the enormous possibilities of literature. Terms and concepts about such phenomena as weights, measurements, forms of addressing people, patterns of formality in speech behaviour, food items, religious practices and many other human activities are easily assimilated by the reader from their reading of translated texts.

All these are to show that the translator of African literary texts is not only an artist helping to re-create a text in another language thus allowing it to survive in that other linguistic medium, but a cultural diplomat who allows members of his linguistic community to be aware of the virtues or even limitations of another culture. Since a literary text is a work of imagination, based on both a private and collective experience, its entry into another language enables its new audience to identify, appreciate and learn from the responses of members of another linguistic and cultural group to their existential realities.

But as at present, not enough has been done to reveal the rich vitality of African literature, through translation. For example, texts written in Spanish and Portuguese have not been very much affected by translation into English and French; so too have very few texts written in English and French managed to cross over to the other two linguistic communities, through translation. Moreover, too little has been done from European languages into indigenous languages. Publishing houses, professionally trained translators, competent bilingual scholars and national or continental associations of translators must take up the challenge very seriously.

Notes and References

* Paper presented at the 4th International Conference of the Nigerian Association of Translators and Interpreters (NATI). April 1985.

1. The population of the world by 1982 was 5719000000 according to World Population Report, Table 19, Oxford University Press, pp. 254-255.

2. As far as African literature is concerned, the language being used in translation is not the translator's native language. This is the situation with Africans translating into a European language.

3. E.A. Nida (1964) : Towards a Science of Translating, Leiden, pp. 166-167.

4. Chinua Achebe (1975) : "The African Writer and the English Language", in Morning Yet on Creation Day, London, Heinemann, p. 61.

5. Ferdinand Oyono (1956): Une vie de Boy, Julliard, p. 14.

6. Gerardo Vázquez-Ayora (1979) : "Semiostylistics : Stylistics plus Interpretation", Babel, No 4, Vol. XXV, p. 205.

7. Nicolay Chukovsky in Victor Borissov (1981) : "Literature Brings People Together", la Traduction et la coopération culturelle internationale, Colloque international, Sofia-Presse, p. 143.

8. Ibid., p. 41. (Discours du Directeur général de l'UNESCO.)

9. André Lefevère (1975) : Translating Poetry : Seven Strategies and a Blueprint, Van Gorcum Comp. B.V. Assen, p. 105. mu 